\title{
Vitamin C and Total Antioxidant Content in Pepper Fruits (Capsicum annuum L.): Comparative Analysis of Peppers Grown in Conventional and Organic Agricultural Systems
}

\author{
Olivera Bicikliski ${ }^{*}$, Fidanka Trajkova ${ }^{1}$, Ljupco Mihajlov ${ }^{1}$, Suzana Jordanovska $^{2}$ \\ and Krste Tashev ${ }^{3}$ \\ ${ }^{1}$ Faculty of Agriculture, Goce Delcev University, Krste Misirkov, 10-A, P.O.Box 201, 2000 Stip, \\ Republic of Macedonia. \\ ${ }^{2}$ Institute of Agriculture, Skopje, $16^{\text {th }}$ Macedonian Brigade, 3A, 1000 Skopje, Republic of Macedonia. \\ ${ }^{3}$ State Phytosanitary Laboratory, Aleksandar Makedonski B.B., 1000 Skopje, Republic of Macedonia.
}

Authors' contributions

This work was carried out in collaboration among listed authors. Author OB planned and carried the field experimental work performed the results analysis, literature collection and manuscript writing. Author FT participated in planning of the field experimental work, statistical analysis and manuscript preparation. Author LM was responsible for overall planning and supervision of the experiment and participated in manuscript preparation. Authors SJ and KT contributed with the applied laboratory methodology for extraction of vitamin $C$ and total antioxidants and quantification of vitamin $C$. All authors read and approved the final manuscript.

Article Information

DOI: 10.9734/ARRB/2018/42851 Editor(s):

(1) Dr. George Perry, Dean and Professor of Biology, University of Texas at San Antonio, USA.

Reviewers:

(1) Tabe Franklin Nyenty, University of Ngaoundere, Cameroon

(2) Zoran S. Ilić, University of Kosovska Mitrovica, Serbia. Complete Peer review History: http://www.sciencedomain.org/review-history/25513

Original Research Article

Received 23 ${ }^{\text {rd }}$ April 2018

Accepted $8^{\text {th }}$ July 2018

Published $12^{\text {th }}$ July 2018

ABSTRACT

Up-to-date, there is no methodical and long-term research on fruit quality and nutritional characteristics of peppers grown in organic production system in Republic of Macedonia. Still, there are debates in broad sense about the advantage of organic vegetable production compared to conventional one in terms of quality characteristics. Led by this idea, this research was conducted with an aim to study vitamin C content and total antioxidant content in fruits of six pepper genotypes 
as most important fruit quality characteristics and to determine if there are differences in fruit quality properties between those grown in organic and conventional production system.

Fruits of six different pepper genotypes Strumicka Kapija, Strumicka Vezena, Piran, Zupska Rana, Duga Bela and Kurtovska Kapija cultivated in organic and conventional production systems were used for determination of vitamin $C$ and total antioxidant content. The extraction of vitamin $C$ and total antioxidants were performed in a plant tissue extractor with orthophosphoric acid and methanol as extracting reagents, respectively. Vitamin $\mathrm{C}$ content was determined by HPLC instrument, while total antioxidant content was measured with potentionstat instrument.

The genotype Strumicka Kapija was characterized with the highest content of vitamin $\mathrm{C}$ in both cultivation systems. In all genotypes under study, except Zupska Rana, the vitamin C content was higher in fruits from organic production as compared to pepper fruits from the conventional system. Generally, the total antioxidant content in pepper fruits from the conventional system was averagely lower than the total antioxidant content measured in pepper fruits from the organic production system. These findings are a prove that production system is very important for the fruit quality characteristic and the organic production of peppers results with production of fruits with higher content of vitamin $\mathrm{C}$ and antioxidants compared to conventional ones, therefore organic peppers give more nutrition and health benefits to consumers.

Keywords: Capsicum annuum L.; pepper; vitamin C; antioxidants; organic cultivation system; conventional cultivation system.

\section{INTRODUCTION}

Currently, the food which is organically produced gains more popularity among consumers, health educators, farmers and food retailers. Many consumers believe that organically grown vegetables have a better quality, are healthier and contain more nutrients than conventionally cultivated vegetables [1].

Three main factors as genetics, environment and post-harvest practices are found as most important for nutritional composition of vegetables cultivated under organic or conventional conditions [2].

Vitamin $\mathrm{C}$ (ascorbic acid, $\mathrm{C}_{6} \mathrm{H}_{8} \mathrm{O}_{6}$ ) is water soluble vitamin, found in plants, especially in fruits and leaf vegetables, and has a very important function for the immune system, functions in enzymes activation, reduction of oxidative stress and many essential metabolic processes. Vitamin $\mathrm{C}$ is one of the most important indicators for nutritive quality in many agricultural crops and it is generally known that pepper fruit is characterized by the highest content of vitamin $\mathrm{C}$ from all vegetables and fruits. The content of vitamin $C$ in fruits and vegetables can be influenced by various factors such as: genotypic differences, preharvest climatic conditions and cultural practices, maturity as well as harvesting methods and postharvest handling procedures [3].

Antioxidants are beneficial because of their protective roles against multiple diseases such as cancer, anemia, diabetics and cardiovascular diseases. Their function is counteracting the oxidizing effects on lipids by scavenging highly reactive oxygen free radicals, the major oxidizing factors for the oxidative modification of low density lipoprotein and nucleic acids [4]. Limited availability of antioxidants in human body results in health damage [5]. Therefore, antioxidants that remove reactive oxygen species can be of great value for prevention of the harmful effects of oxidative diseases [6].

The most common antioxidants present in vegetables are vitamins $C$ and $E$, carotenoids, flavonoids, sulfuric compounds and it is commonly accepted that foods of plant origin are the most important source of antioxidants [7-9].

From the available literature, there is no methodical and long-term research on fruit quality and nutritional characteristics of pepper crop cultivated in organic production system, in Republic of Macedonia and broader region. Still, there are debates in broad sense about the advantage of organic vegetable production compared to conventional one in terms of quality characteristics. Led by this idea and necessity, this research was conducted with an aim to study vitamin $\mathrm{C}$ and total antioxidant content of fruits of six locally important pepper genotypes as most important fruit quality characteristics and to determine if there are differences in fruit quality properties between those grown in organic and conventional production system.

This is the first comparative research in Republic of Macedonia on fruit quality and nutritional 
characteristics of locally important peppers genotypes (Capsicum annuum L.) cultivated in organic and conventional production system.

\section{MATERIALS AND METHODS}

\subsection{Plant Material}

For this research an experimental field was established at the location Kamnik in Skopje, on the organically certified production fields of Kamnik Bio Organic during three successive years.

Pepper fruits, collected from six different pepper genotypes cultivated under organic and conventional conditions, were used as a plant material in this study: Strumicka Kapija, Strumicka Vezena, Piran, Zupska Rana, Duga Bela and Kurtovska Kapija. For the purpose of this study, five randomly selected pepper fruits from each genotype grown in conventional and organic system were used for preparation of laboratory samples for determination of vitamin C content and total antioxidant content.

The open-field experiment was set according to the random block system method in three repetitions in organic production system and three repetitions in conventional production system for each examined genotype. Each genotype was represented by 15 plants at each repetition, a total of 45 plants from each genotype in the organic production system and a total of 45 plants in the conventional production system.

During the whole vegetation period, proper cultivation practices were applied in the organic and conventional production system, respectively.

In the three experimental years, the sowing was carried out in the last week of March, while the seedlings were transplanted on the open field in the last week of May. The open-field experiment was realized by applying appropriate agrotechnical measures in the organic and conventional production system, using standard agrotechnology for basic and pre-soil preparation of the soil. Pre-soil preparation was performed by plowing and rotovating. For protection against high temperatures and direct sunlight, the experimental field was protected by a $30 \%$ shade protective net.

During the experiment, plant nutrition was performed twice, during the second half of June and July, respectively and adequately in the organic and conventional production system. Plant nutrition in the organic production system was performed with utilization of organic fertilizers Tecamin max and Multi bloom applied through the irrigation system, as well as application of foliar organic fertilizer from sea algae (Ascophyllum nodosum) and $12 \%$ humic acid. In the conventional production system, foliar plant nutrition with Controlphyt PK (30:20) and NPK (15:15:15) fertilizers were applied in combination with soil fertilization with NPK magnesium pellets.

A preventive protection spraying of both systems was carried out 15 days after planting. The organic block was treated with fungicide Copper oxychloride 50 (active substance 50\% copper oxychloride copper) and insecticide NeemazalT/S (active substance Azadiraktin), allowed for use in organic production. The conventional block was preventively treated with fungicide Ridomil Gold MZ pepite (active substances Mankozeb $64 \%$ and M-metalaksil 3.88\%) and with insecticide Actara 25 WG (active substance Tiametoksam).

Since different pepper genotypes were included in the experiment, first and last harvest were performed according to the biological traits of each genotypes, starting from mid of July and finishing during the first week of October.

\subsection{Extraction and Determination Method of Vitamin C Content}

Extraction of vitamin $C$ from selected fruits was performed in a plant tissue extractor, where orthophosphoric acid $\left(\mathrm{H}_{3} \mathrm{PO}_{4}\right)$ was used as extracting reagent with a concentration of $\mathrm{c}\left(\mathrm{H}_{3} \mathrm{PO}_{4}\right)=5 \times 10^{3} \mathrm{~mol} / \mathrm{L}$ and carefully adjusted to $85 \% \mathrm{H}_{3} \mathrm{PO}_{4}, \mathrm{pH}=3$.

The pepper tissue of $5 \mathrm{~g}$ was mixed with $5 \mathrm{ml}$ of the extraction reagent and passed through plant tissue extractor. After the extraction, $100 \mathrm{ul}$ extracts were taken and diluted with $1400 \mathrm{ul}$ water with HPLC qualities. All samples were filtered through 0.45 um filters before injection in HPLC instrument.

Determination of vitamin C content was done on Varian Pro Star HPLC. The mobile phase was methanol : water $=5: 95(\mathrm{v} / \mathrm{v})$ with isocratic flow of $1 \mathrm{ml} / \mathrm{min}$. Determination was performed on wavelength of $254 \mathrm{~nm}$, injected volume $10 \mu \mathrm{l}$ for total analysis time of $7 \mathrm{~min}$. 
The calibration of the instrument was performed with vitamin $\mathrm{C}$ standard solutions. A basic standard of vitamin C 'stocks' was prepared with a concentration of $1000 \mathrm{mg} / \mathrm{L}$ in the extraction reagent. Standards of $10,30,60,90$ and 120 $\mathrm{mg} / \mathrm{L}$ in the extraction reagent were prepared from the stock solution.

The calibration curve characteristics of applied methodology were $y=1835998.631 x+1277495$ with correlation characteristics $p>0.99$ (Fig. 1, Fig. 2).

\subsection{Extraction and Determination of Total Antioxidant Content}

Extraction of total antioxidants from the selected fruits was performed in a plant tissue extractor, where methanol was used as extracting reagent. In a semipermeable bag were put $5 \mathrm{~g}$ sample and $5 \mathrm{ml}$ of methanol. After the extraction process was done, the material was transferred in a $50 \mathrm{ml}$ tube with additional $5 \mathrm{ml}$ of methanol, and centrifuged at $3000 \mathrm{rpm}$.

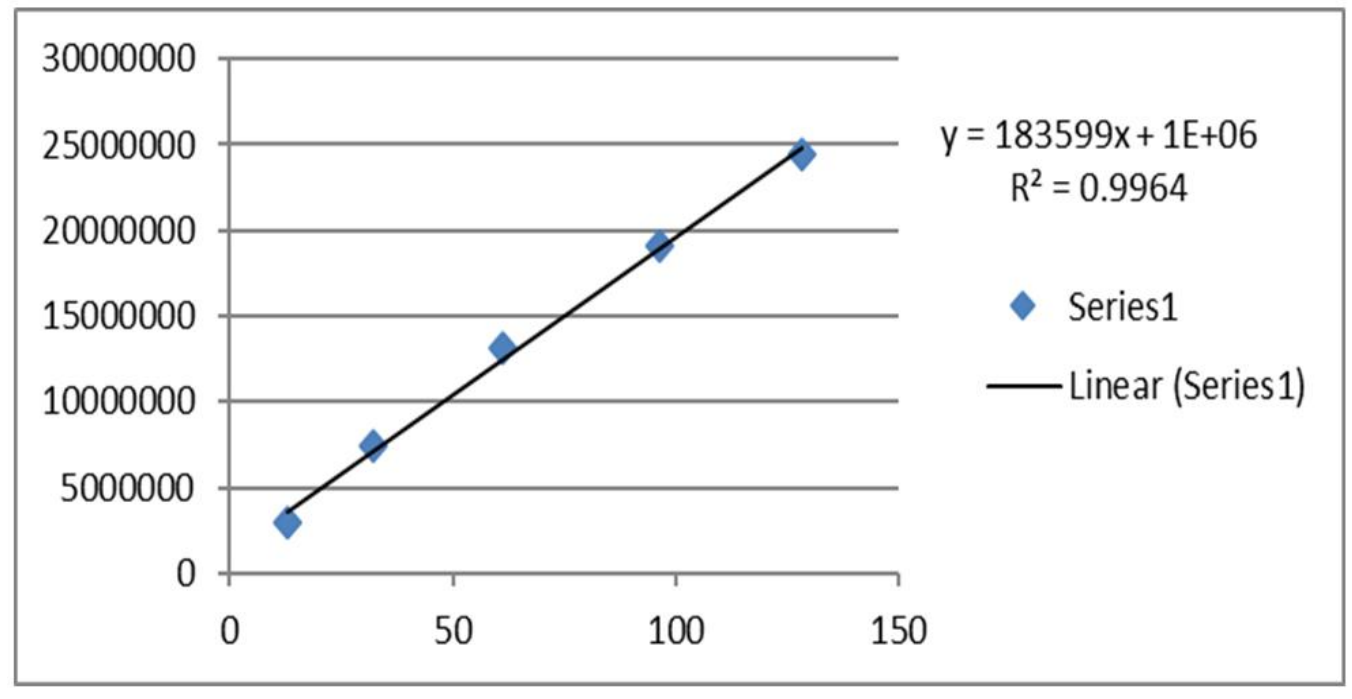

Fig. 1. Calibration curve characteristics of vitamin C standards

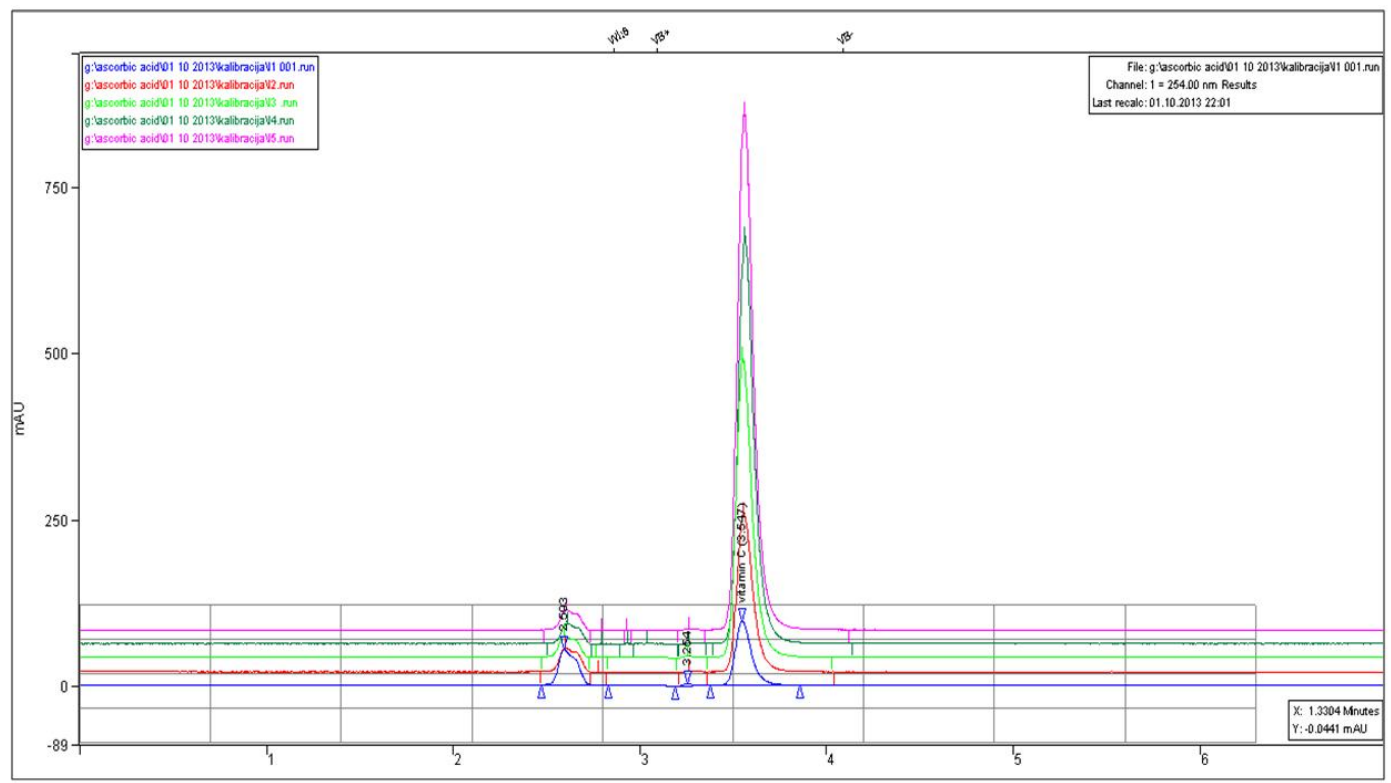

Fig. 2. Chromatogram of the calibration levels of vitamin C on HPLC instrument 
Determination of antioxidant content was done using the Autolab PGstat $128 \mathrm{~N}$ instrument [10]. The total antioxidant potential was calculated using the electrolytic regenerative mechanism of ABTS (ABTS-2,2'-azinobis (3-ethylbenzothiazoline-6-sulfonic acid)) compound. The obtained results will be shown in relation to the antioxidative potential of vitamin $\mathrm{C}$. The oxidation of the ABTS compound in the presence of a pepper extract is accompanied by an increase in the measured electricity due to the chemical interaction of the antioxidants present in the peppers and the oxidized forms of the ABTS compound that regenerate the working electrode during the volumetric experiments.

The total antioxidant potential is compared in terms of the potential of vitamin $\mathrm{C}$, which is considered as a standard. The measured values of the antioxidant potential of the pepper extract are in direct correlation with the quality of the peppers. The applied method is relatively quick and simple to perform, and the only deficit that it cannot recognize the individual antioxidant effects of the individual antioxidant present in the peppers [10].

\subsection{Statistical Analysis of Data}

Statistical analysis of univariate analysis of variance (ANOVA) was used for evaluation and comparison of the organic and conventional production practice effect on vitamin $C$ and total antioxidant content in pepper fruits under study with IBM SPSP Statistics Software 19.0.

\section{RESULTS AND DISCUSSION}

\subsection{Vitamin C Content in Pepper Fruits from Organic and Conventional Cultivation System}

The results of vitamin $\mathrm{C}$ content in the pepper fruits from organic and conventional production system are presented in Table 1, while an example of chromatogram of measured vitamin C content in a pepper fruit sample is given in Fig. 3.

The highest content of vitamin $\mathrm{C}$ was measured in the pepper fruit from the genotype Strumicka Kapija in both production systems (142.07 and $118.47 \mathrm{mg} / \mathrm{g}$, respectively). The lowest content of vitamin $\mathrm{C}$ under the organic production conditions was measured in Zupska Rana (48.18 $\mathrm{mg} / \mathrm{g}$ ), while in the conventional production system the lowest content of vitamin $\mathrm{C}$ showed Piran $(45.23 \mathrm{mg} / \mathrm{g})$. In pepper fruits of all genotypes, except Zupska Rana, the vitamin C content in fruits from organic production system was higher as compared to vitamin C content found in fruits from conventional production system.

The most important influence on vitamin $C$ content has the genotype $\left(\eta^{2}=0.722\right)$, while the method of cultivation has a much lower effect $\left(n^{2}\right.$ $=0.070)$. In terms of interaction between the different pepper genotypes and cultivation practice, as factors that influence the content of vitamin $\mathrm{C}$, this interaction was found to be low and amounted to $\eta^{2}=0.330$ (Table 2).

Table 1. Vitamin C content in pepper fruits of different genotypes cultivated in organic and conventional production system

\begin{tabular}{llll}
\hline Genotype & Production practice & Mean value $\mathbf{( m g / g )}$ & Standard deviation \\
\hline Strumicka Kapija & organic & 142.07 & 8.44 \\
& conventional & 118.47 & 21.63 \\
Strumicka Vezena & organic & 78.67 & 15.26 \\
& conventional & 72.45 & 9.28 \\
Piran & organic & 62.57 & 8.16 \\
& conventional & 45.23 & 31.37 \\
Zupska Rana & organic & 48.18 & 15.18 \\
& conventional & 84.12 & 21.39 \\
Duga Bela & organic & 96.33 & 14.48 \\
& conventional & 65.62 & 15.89 \\
Kurtovska Kapija & organic & 102.77 & 18.03 \\
& conventional & 94.22 & 1.09 \\
\hline
\end{tabular}




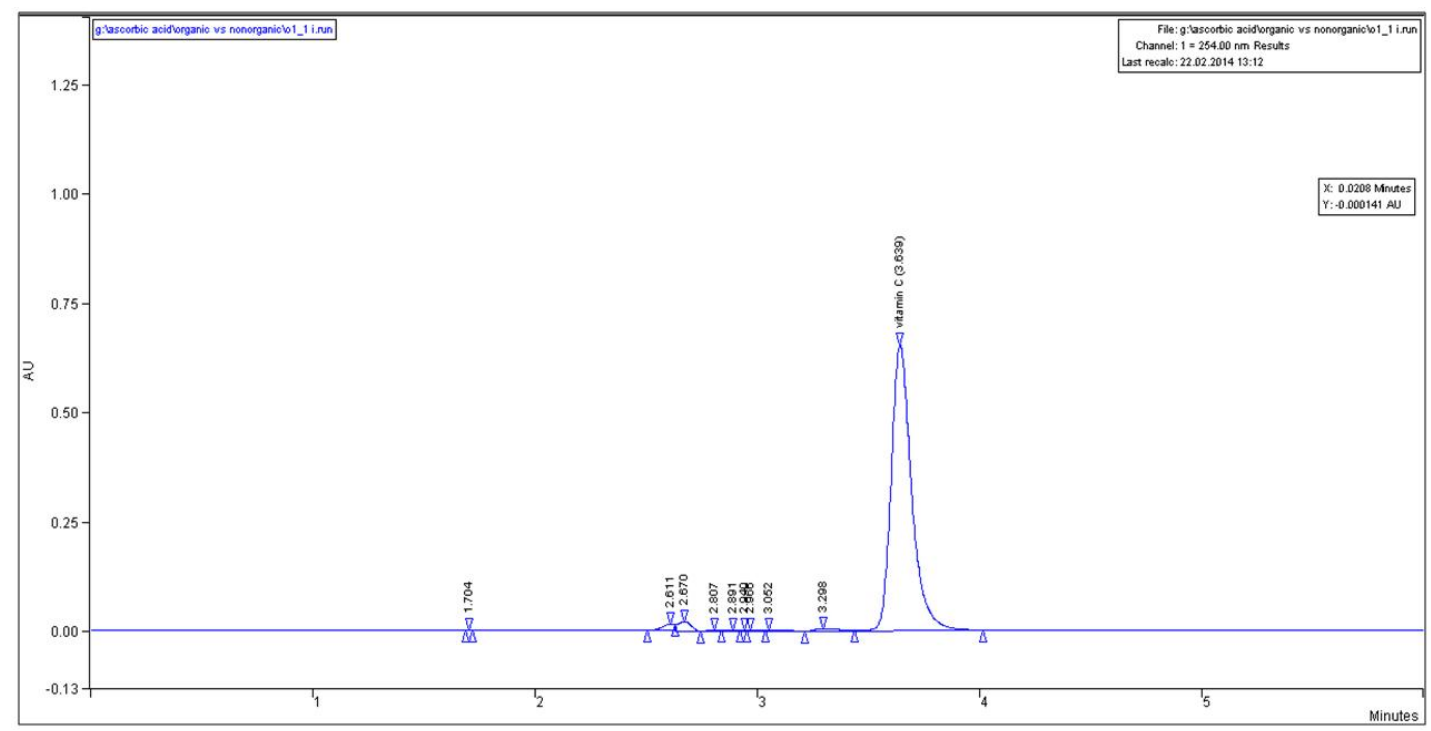

Fig. 3. Chromatogram of vitamin $\mathrm{C}$ content in a pepper fruit sample

Table 2. Univariate analysis of the effect of pepper genotypes and cultivation practice on vitamin $\mathrm{C}$ content in their fruits

\begin{tabular}{|c|c|c|c|c|c|c|}
\hline Factor & $\begin{array}{l}\text { Sum of } \\
\text { squares }\end{array}$ & $\begin{array}{l}\text { Degree of } \\
\text { freedom (df) }\end{array}$ & $\begin{array}{l}\text { Mean } \\
\text { square }\end{array}$ & F test & Significant & $\begin{array}{l}\text { Effect of factor } \\
\text { (Partial eta squared) }\end{array}$ \\
\hline Genotype & 43864.292 & 5 & 8772.858 & 31.093 & 0.000 & 0.722 \\
\hline $\begin{array}{l}\text { Cultivation } \\
\text { practice }\end{array}$ & 1274.283 & 1 & 1274.283 & 4.516 & 0.038 & 0.070 \\
\hline $\begin{array}{l}\text { Genotype * } \\
\text { Cultivation } \\
\text { practice }\end{array}$ & 8337.332 & 5 & 1667.466 & 5.910 & 0.000 & 0.330 \\
\hline $\begin{array}{l}\text { Error } \\
\text { Total }\end{array}$ & $\begin{array}{l}16929.082 \\
581145.390\end{array}$ & $\begin{array}{l}60 \\
72\end{array}$ & 282.151 & & & \\
\hline
\end{tabular}

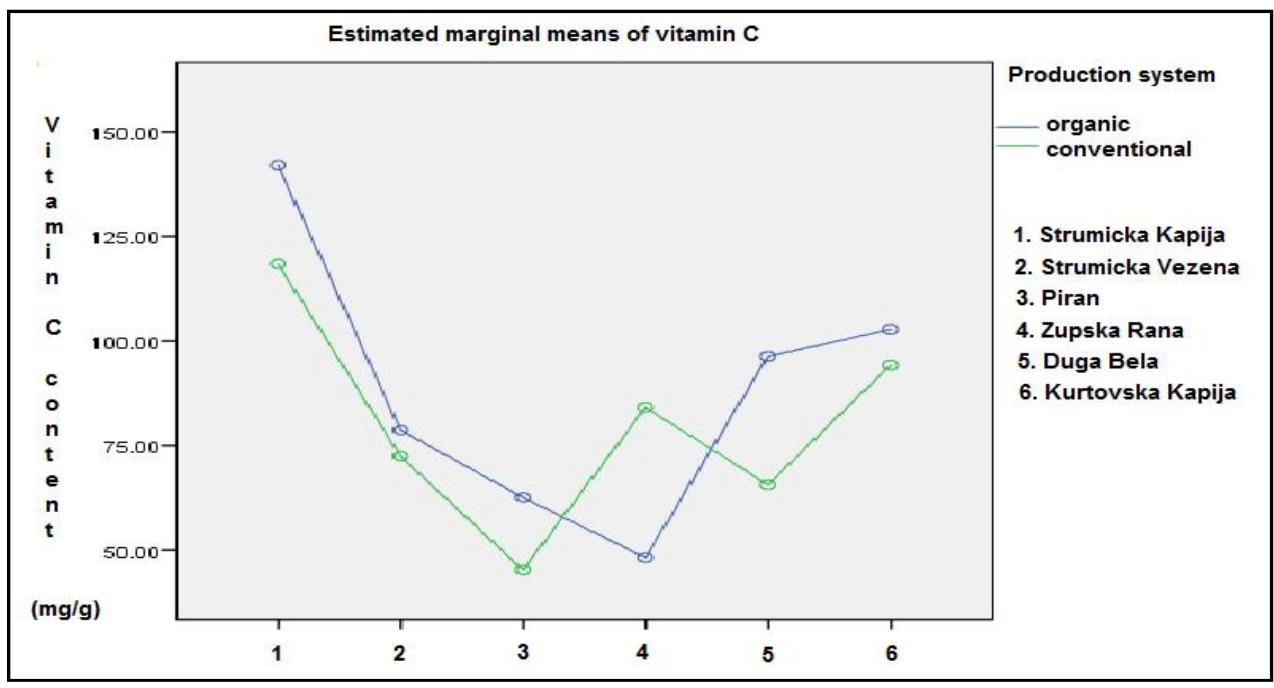

Fig. 4. Estimated marginal means of vitamin $C$ content in pepper fruits of tested genotypes cultivated in organic and conventional production system 
Although the previous analysis of the influence of the genotype and the cultivation, expressed through the strength of the factor, showed very little effect on vitamin $C$ content, the analysis by separate genotypes of pepper indicates that except for the genotype Zupska Rana, where the content of vitamin $C$ was greater in the conventional production system, in all other genotypes the content of vitamin $\mathrm{C}$ was higher in the organic production system (Fig. 4). Also, the comparative analysis of vitamin $\mathrm{C}$ content in different genotypes grown in an organic and conventional production system showed that the genotypes grown in the conventional system had averagely $8.414 \mathrm{mg} / \mathrm{g}$ lower vitamin C content compared to fruits cultivated in the organic system with a statistically significant difference (Table 3).

Generally, organically grown vegetables contain higher quantities of vitamins and minerals as compared to conventionally grown vegetables. Smith [11] reported that organic food contains more nutritious in terms of mineral content than produced under conventional conditions. Leclerc et al. [12] found that carrots and celeriac roots grown organically were higher in ascorbic acid and $\beta$-carotene contents. In addition, the same authors reported that the ascorbic acid content in potatoes grown organically was significantly higher than those grown under the conventional method. On the other hand, authors reported no significant difference in the ascorbic acid content in potato, tomato and pepper grown using these two production methods [13] and no differences in $\beta$-carotene content of carrots grown under organic and conventional fertilization [14]. However, Topuz and Ozdemir [15] reported that differences in vitamin $\mathrm{C}$ content in various pepper genotypes are highly influenced by the genetic diversity of genotypes investigated.

Ismail [1] in the research regarding determination of vitamin $C, \beta$-carotene and riboflavin contents in five green vegetables cultivated under organic and conventional conditions and selected according to the popularity of consumption in Malaysia, noted that environment and postharvest practices were separated as factors that can affect the content of vitamins in the fruits. The author considers that it was extremely difficult to make a true comparison between the two ways of production. However, the study was useful as a step towards further work to create a vitamin-based database for organic vegetables. The same applies to this research and all other studies related to comparative analyzes in the content of vitamins and other nutrients of products under organic and conventional farming systems [1].

The research of Korkutata and Kavaz [16] also confirms the influence of pepper genotype on the content of vitamin C. Differences were found in the content of vitamin $\mathrm{C}$ in different red hot pepper genotypes grown in a conventional production system. The content of ascorbic acid in pepper fruit depends not only on the variety, but also on the method of production [17] and a higher content of vitamin $\mathrm{C}$ was measured in peppers from organic production than conventional was reported [18]. Hallmann and Rembiałkowska [19] found that the fruits of peppers grown in the organic system were characterized by significantly higher content of vitamin $\mathrm{C}$ than those of the conventional system of cultivation.

\subsection{Total Antioxidant Content in Pepper Fruits from Organic and Conventional Cultivation System}

The results of total antioxidant content in the pepper fruits from organic and conventional production system are presented in Table 4.

The highest total antioxidant content was determined in pepper fruits of Piran $(1.18 \mathrm{mg} / \mathrm{g})$, while the lowest was measured in pepper fruits of Duga Bela $(0.71 \mathrm{mg} / \mathrm{g})$, both from the conventional system. Comparing the both production systems, we found the highest total antioxidant content in the genotype Strumicka Kapija (1.08 $\mathrm{mg} / \mathrm{g})$ and the lowest content in the genotype Kurtovska Kapija (0.91 $\mathrm{mg} / \mathrm{g})$ in the organic system. On the other hand, in the conventional production system, the highest antioxidant content was measured in pepper fruits of Strumicka Kapija (1.13 $\mathrm{mg} / \mathrm{g})$ and the lowest content in the pepper fruits of Duga Bela (0.71 mg/g).

The genotype had a superior influence on the total antioxidant content in pepper fruits $\left(\eta^{2}=\right.$ 0.112 ), while the cultivation method had much less effect $\left(n^{2}=0.014\right)$. In terms of interaction between the pepper genotypes and the cultivation practice, as factors that influence the content of antioxidants, it had been shown that this interaction is low and amounts to $\eta^{2}=0.087$ (Table 5). 
Table 3. Pairwise comparison between vitamin $C$ content in pepper fruits and cultivation system applied

\begin{tabular}{lllll}
\hline $\begin{array}{l}\text { (A) Cultivation } \\
\text { system }\end{array}$ & $\begin{array}{l}\text { (B) Cultivation } \\
\text { system }\end{array}$ & $\begin{array}{l}\text { (A-B) Mean } \\
\text { difference }\end{array}$ & Std. error & Significance $^{\mathbf{b}}$ \\
\hline Organic & Conventional & $8.414^{*}$ & 3.959 & 0.038 \\
Conventional & Organic & $-8.414^{*}$ & 3.959 & 0.038 \\
\hline \multicolumn{5}{c}{ b. Adjustment for } \\
multiple comparisons: Least Significant Difference (equivalent to no adjustments)
\end{tabular}

Table 4. Total antioxidant content in pepper fruits of different genotypes cultivated in organic and conventional production system

\begin{tabular}{llll}
\hline Genotype & Production practice & Mean value $\mathbf{( m g / g )}$ & Standard deviation \\
\hline Strumicka Kapija & organic & 1.08 & 0.23 \\
& conventional & 1.13 & 0.39 \\
Strumicka Vezena & organic & 0.94 & 0.07 \\
& conventional & 0.96 & 0.16 \\
Piran & organic & 1.18 & 0.24 \\
& conventional & 0.90 & 0.13 \\
Zupska Rana & organic & 0.99 & 0.15 \\
& conventional & 0.87 & 0.26 \\
Duga Bela & organic & 0.92 & 0.11 \\
\multirow{2}{*}{ Kurtovska Kapija } & conventional & 0.71 & 0.33 \\
& Organic & 0.91 & 0.12 \\
\hline
\end{tabular}

Table 5. Univariate analysis of the effect of pepper genotypes and cultivation practice on total antioxidant content in their fruits

\begin{tabular}{lllllll}
\hline Factor & $\begin{array}{l}\text { Sum of } \\
\text { Squares }\end{array}$ & $\begin{array}{l}\text { Degree of } \\
\text { freedom } \\
\text { (df) }\end{array}$ & $\begin{array}{l}\text { Mean } \\
\text { square }\end{array}$ & F test & Significant & $\begin{array}{l}\text { Effect of } \\
\text { factor } \\
\text { (Partial eta } \\
\text { squared) }\end{array}$ \\
\hline Genotype & 0.593 & 5 & 0.119 & 1.518 & 0.198 & 0.722 \\
Cultivation practice & 0.068 & 1 & 0.068 & 0.868 & 0.355 & 0.070 \\
$\begin{array}{l}\text { Genotype * } \\
\text { Cultivation practice } \\
\begin{array}{l}\text { Error } \\
\text { Total }\end{array}\end{array}$ & 0.447 & 5 & 0.089 & 1.145 & 0.347 & 0.330 \\
\hline
\end{tabular}

Although the previous analysis of the influence of the genotype and the cultivation practice, expressed through the strength of the factor, showed very little influence on the total antioxidant content, the analysis of relationship between pepper genotypes and total antioxidant content in pepper fruits indicates that the organic production system in the genotypes Piran, Zupska Rana and Duga Bela contributed to higher total antioxidant content as compared to the conventional ones. On contrary, a higher content of total antioxidant was measured in pepper fruits of Strumicka Kapija, Strumicka Vezena and Kurtovska Kapija in conventional production system (Fig. 5).

However, the pairwise comparison between the total antioxidant content in pepper fruits from different genotypes grown in organic and conventional production system showed that the peppers grown in the conventional system have averagely $0.061 \mathrm{mg} / \mathrm{g}$ lower total antioxidant content than the pepper fruits from the organic production system (Table 6).

Antioxidant compounds in pepper fruits are influenced by genotype, timing of harvest and weather conditions during the entire vegetation period [19-20]. Plant nutrition with mineral fertilizers in production process reduces antioxidant content, while organic fertilizers contributes to increase of content of antioxidants in plants [21-23]. However, there are different data regarding the phytochemical status of organic and conventional vegetables [24-25]. Antioxidant activity depends on different 


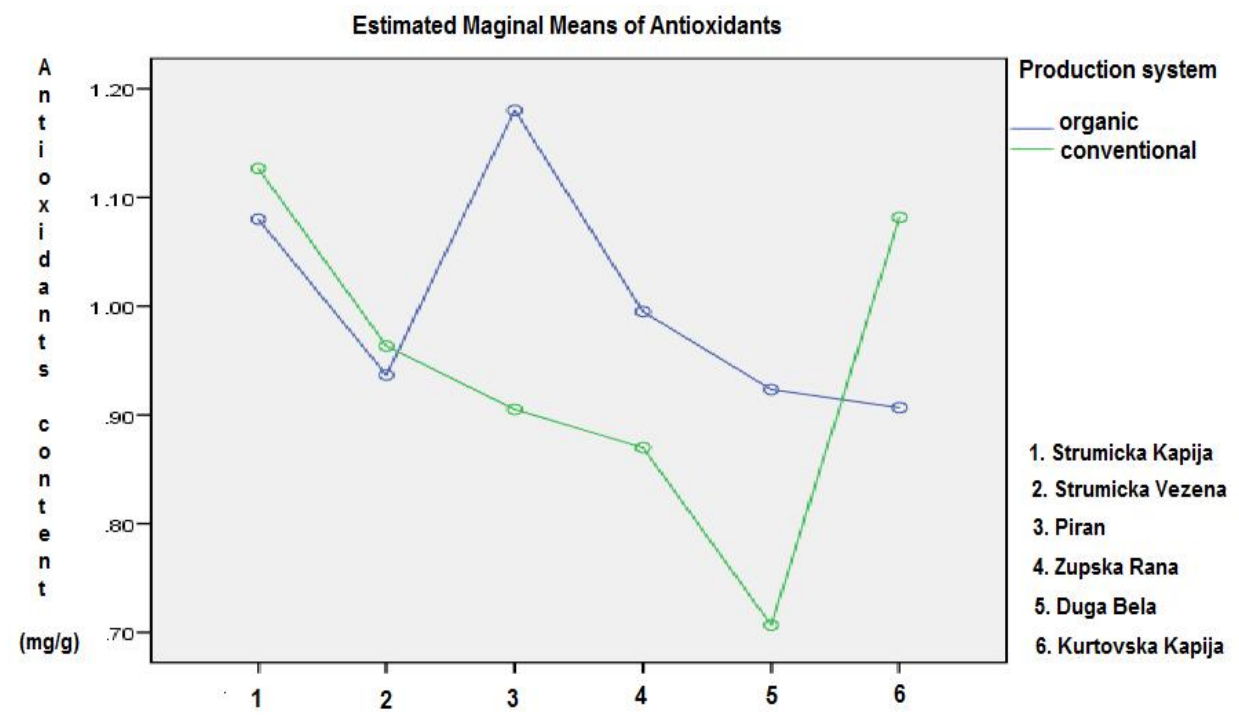

Fig. 5. Estimated marginal means of total antioxidant content pepper fruits of tested genotypes cultivated in organic and conventional production system

Table 6. Pairwise comparison between total antioxidant content in pepper fruits and cultivation system applied

\begin{tabular}{lllll}
\hline $\begin{array}{l}\text { (A) Cultivation } \\
\text { system }\end{array}$ & $\begin{array}{l}\text { (B) Cultivation } \\
\text { system }\end{array}$ & $\begin{array}{l}\text { (A-B) Mean } \\
\text { difference }\end{array}$ & Std. error & Significance $^{\mathbf{b}}$ \\
\hline Organic & Conventional & 0.061 & 0.066 & 0.355 \\
Conventional & Organic & -0.061 & 0.066 & 0.355 \\
\hline
\end{tabular}

${ }^{*}$. The mean difference is significant at the 0,05 level.

b. Adjustment for multiple comparisons: Least Significant Difference (equivalent to no adjustments).

chemical properties and can be specific for each variety. It mainly depends mostly on phenols, which are considered to be stronger antioxidants compared to vitamins [26-27].

Szafirowska and Elkner (2008) [17] determined a large amount of total flavonoids and soluble phenols, as well as a significantly higher content of beta-carotene in organic fruits of peppers of three varieties (average $1.1 \mathrm{mg} / 100 \mathrm{~g}$ ) as compared to fruits from conventional production (average of $0.8 \mathrm{mg} / 100 \mathrm{~g}$ ). There was a report for higher content of total flavonoids and soluble phenols in organically grown tomatoes compared to those grown in a conventional system [28]. On the other hand, Knap et al. [29] reported no significant differences in the antioxidant activity between the organically and conventionally grown crops and spices. Furthermore, Maksimova et al. [30-31] reported a significant relationship between capsaicinoids content and antioxidant activity of four different genotypes of pepper (Capsicum annuum L.).

\section{CONCLUSION}

Vitamin C content found in pepper fruit of six genotypes grown in organic and conventional cultivation systems varies due to pepper genotypes diversity and applied cultivation practices. The highest vitamin C content was measured in Strumicka Kapija grown in both cultivation systems. Overall, the value of vitamin C content was higher in pepper fruits from organic cultivation in all tested genotypes, except Zupska Rana. The comparison between the total antioxidant content in pepper fruits from different genotypes grown in organic and conventional production system showed that the peppers grown in the conventional system have averagely lower total antioxidant content than the pepper fruits from the organic production system.

These findings are a confirmation that production system is very important for the fruit quality characteristic and the organic production of peppers results with production of fruits with higher content of vitamin $\mathrm{C}$ and antioxidants 
compared to conventional ones, therefore organic peppers give more nutrition and health benefits to consumers. Nevertheless, there is an imperative need for further research and study of quality parameters of organically cultivated vegetables, as a scientifically based evidence to support opinions that organically cultivated vegetables give more health and nutritive advantages over conventional ones.

\section{COMPETING INTERESTS}

Authors have declared that no competing interests exist.

\section{REFERENCES}

1. Ismail A. Determination of vitamin $C, \beta-$ carotene and riboflavin contents in five green vegetables organically and conventionally grown. Malaysian Journal of Nutrition. 2003;9(1):31-9.

2. Salunkhe DK, Desai BB. Effects of agricultural practices, handling, processing and storage on vegetables. In: Karmas E, Harris RS, edditors. Nutritional evaluation of food processing, $3^{\text {rd }}$ ed. New York: Van Nostrand Reinhold; 1988.

3. Lee SK, Kader A. Preharvest and postharvest factors influencing vitamin C content of horticultural crops, Postharvest Biology and Technology. 2000;20,207-220.

4. Perucka I, Materska M. Antioxidant vitamin contents of Capsicum annuum fruit extracts as affected by processing and varietal factors. Acta Sci. Pol., Technol. Aliment. 2007;6(4),67-74.

5. Cheeseman $\mathrm{KH}$, Slater TF. Free radical in medicine. Br. Med. Bull. 1994;49:479-724.

6. Willet WC. Diet and health what should we eat ? Science. 1994;264:532-537.

7. Hertog MGL, Hollman PCH. Potential health-effects of the dietary flavonol quercetin. Eur J Clin Nutr. 1996;50(2):6371.

8. Pietta PG. Flavonoids as antioxidants. J. Nat. Prod. 2000;63:1035-1042.

9. Chandrasekara A, Shahidi F. Determination of antioxidant activity in free and hydrolyzed fractions of millet grains and characterization of their phenolic profiles by HPLC-DAD-ESI-MSn. J. Funct. Foods. 2011;3:144-58.

10. Gulaboski R, Mirčeski V, Mitrev S. Development of a rapid and simple voltammetric method to determine total antioxidative capacity of edible oils. Food Chem. 2013;138(1):116-21.

11. Smith BL. Organic foods vs. supermarket foods: Element Levels. J Appl Nutr. 1993; 45(1):35-39.

12. Leclerc J, Miller ML, Joliet E, Rocquelin G. Vitamin and mineral contents of carrot and celeriac grown under mineral or organic fertilization. Biological Agriculture \& Horticulture. 1991;7,(4):339-348.

13. Svec LF, Thoroughgood CA, Mok HC. Chemical evaluation of vegetables grown with conventional or organic soil amendments. Communication Soil Science Plant Analysis. 1976;7:213.

14. Eggert FP, Kahrmann CL. Response of three vegetable crops to organic and inorganic nutrient sources. Organic farming: current technology and its role in sustainable agriculture. 1984;97-109.

15. Topuz A, Ozdemir F. Assessment of carotenoids, capsaicinoids and ascorbic acid composition of some selected pepper cultivars (Capsicum annuum L.) grown in Turkey. J Food Compost Anal. 2007;20: 596-602.

16. Korkutata NF, Kavaz AA. Comparative study of ascorbic acid and capsaicinoid contents in red hot peppers (Capsicum annum L.) grown in southeastern Anatolia region. Int J Food Prop. 2015;18:725-734.

17. Szafirowska A, Elkner K. Yielding and fruit quality of three sweet pepper cultivars from organic and conventional cultivation. Vegetable Crops Research Bulletin. 2008; 69:135- 143.

18. Szafirowska A, Elkner K. The comparison of yielding and nutritive value of organic and conventional pepper fruits. Vegetable Crops Research Bulletin. 2009;71:111121.

19. Hallmann E, Rembiałkowska E. Characterisation of antioxidant compounds in sweet bell pepper (Capsicum annuum L.) under organic and conventional growing systems. J Sci Food Agric. 2012; 92:2409-2415.

20. Lee Y, Howard LR. Flavonoids and antioxidant activity of fresh pepper (Capisicum annuum) cultivars. J. Food Sci. 1995;60:473-476.

21. Dumas $Y$, Dadomo M, Di Lucca G, Grolier $P$. Effects of environmental factors and agricultural techniques on antioxidant 
content of tomatoes. J Sci Food Agric. 2003;83:369-382.

22. Aldrich HT, Salandanan $K$, Kendall $P$, Bunning $M$, Stonaker $F$, Kulen $O$, Stushnoff C. Cultivar choice provides options for local production of organic and conventionally produced tomatoes with higher quality and antioxidant content. J Sci Food Agric. 2010;90:25482555.

23. Oliveira $A B$, Moura CF, Gomes-Filho E, Marco CA, Urban L, Miranda MR. The impact of organic farming on quality of tomatoes is associated to increased oxidative stress during fruit development. PLoS One. 2013;8(2):e56354.

24. Faller ALK, Fialho E. Polyphenol content and antioxidant capacity in organic and conventional plant foods. J Food Compost Anal. 2010;23:561-568.

25. Sinkovič L, Demšar L, Žnidarčič D, Vidrih R, Hribar J, Treutter D. Phenolic profiles in leaves of chicory cultivars (Cichorium intybus L.) as influenced by organic and mineral fertilizers. Food Chem. 2015;166: 507-13.

26. Koleva II, Van Beek TA, Linssen JP, Groot $A D$, Evstatieva LN. Screening of plant extracts for antioxidant activity: A comparative study on three testing methods. Phytochem Anal. 2002;13(1):817.

27. Usenik V, Fabcic J, Stampar F. Sugar, organic acids, phenolic composition and antioxidant activity of sweet cherry (Prunus avium L.). Food Chem. 2008;107:185-192.

28. Rembialkowska E. Organic farming as a system to provide better vegetable quality. International Conference on Quality in Chains. An Integrated View on Fruit and Vegetable Quality. 2003;604:473-479.

29. Knap M, Ogrinc N, Potočnik K, Vidrih R. Antioxidant activity in selected slovenian organic and conventional crops. Acta Agric. 2014;103(2):281-289.

30. Maksimova V, Mirceski V, Gulaboski R, Koleva GL, Arsova SZ. Electrochemical evaluation of the synergistic effect of the antioxidant activity of capsaicin and other bioactive compounds in Capsicum sp. extracts. Int. J. Electrochem. Sci. 2016;11: 6673-6687.

31. Maksimova V, Koleva GL, Ruskovska T, Gulaboski R. Determination of total antioxidative capacities of capsacinoids in Capsicum species cultivated in Republic of Macedonia. Yearbook 2014, Goce Delcev University - Stip, Faculty of Agriculture. 2014;12:101-110.

(c) 2018 Bicikliski et al.; This is an Open Access article distributed under the terms of the Creative Commons Attribution License (http://creativecommons.org/licenses/by/4.0), which permits unrestricted use, distribution, and reproduction in any medium, provided the original work is properly cited.

Peer-review history:

The peer review history for this paper can be accessed here: http://www.sciencedomain.org/review-history/25513 